\title{
Uncertainty and the History of Ideas
}

\author{
Adrian Blau ${ }^{1}$ \\ (forthcoming in History and Theory, October 2011)
}

Abstract: Intellectual historians often make empirical claims, but can never know for certain if these claims are right. Uncertainty is thus inevitable for intellectual historians. But accepting uncertainty is not enough: we should also act on it, by trying to reduce and report it. We can reduce uncertainty by amassing valid data from different sources to weigh up the strengths and weaknesses of competing explanations, rather than trying to "prove" an empirical claim by looking for evidence which fits it. Then we should report our degree of certainty in our claims. When we answer empirical questions in intellectual history, we are not telling our readers what happened: we are telling them how strong we think our evidence is -- a crucial shift of emphasis. For intellectual historians, then, uncertainty is subjective, as discussed by Keynes and Collingwood; the paper thus explores three differences between subjective and objective uncertainty. Having outlined the theoretical basis of uncertainty, the paper then offers examples from actual research: Noel Malcolm's work shows how to reduce and report uncertainty about composition, while David Wootton's work shows how to reduce and report uncertainty about composition about beliefs.

Keywords: Collingwood, history of ideas, history of political thought, interpretation, methodology, uncertainty, Quentin Skinner.

\footnotetext{
${ }^{1}$ I thank Brian Fay and my anonymous reviewers for their helpful comments and criticisms on an earlier version of this article.
} 


\section{Introduction}

Intellectual historians often ask empirical questions. Why did Plato write The Republic? When did Machiavelli write the Discourses? What did Jefferson mean by "virtue"? Many of us think there are right answers to these questions. But we accept that we cannot know for certain if our answers are right.

Uncertainty is thus inevitable for intellectual historians. The central message of this paper is that we must actively tackle uncertainty, by reducing and reporting it. We can reduce uncertainty by amassing valid data from different sources to weigh up the strengths and weaknesses of competing explanations, rather than trying to "prove" an empirical claim by looking for evidence which fits it. Then we should report our degree of certainty in our claims. When we answer empirical questions in intellectual history, we are not telling our readers what happened: we are telling them how strong we think our evidence is -- a crucial shift of emphasis.

My basic argument has three parts: (a) intellectual historians often make empirical claims, (b) we can never know for certain if our empirical claims are right, and (c) we should try to reduce and report uncertainty. I mainly emphasize (c), but a brief justification of (a) and (b) will help. The paper thus starts by discussing the kinds of empirical claims that intellectual historians make (section II), then highlights the uncertainty of empirical claims, drawing on Collingwood and Skinner (section III). I significantly modify King, Keohane and Verba's account of uncertainty, in order to offer practical advice on reducing uncertainty (section IV) and on reporting uncertainty (section V). I then explain why reporting uncertainty matters (section VI), before giving examples from actual research: Noel Malcolm and David Wootton exemplify good practice in reducing and reporting uncertainty, with respect to empirical claims about textual composition and authors' beliefs, respectively (sections VII and VIII). 


\section{Empirical claims in intellectual history}

Two kinds of empirical phenomenon are especially important for intellectual historians: actions and beliefs. Much of our focus on actions involves the composition of texts. One issue is authorship. Did Plato write the Seventh Letter? Which changes in the final edition of Hume's Essays were by Hume, and which were by the printers? Another issue is chronology. When did Locke write the Two Treatises? Did Cicero write De legibus before, during or after De re publica? Aside from the composition of texts, we sometimes examine their reception. How much of Condorcet's work did Madison know? Who read Bolingbroke in the 1790s, and did anyone read him all of the way through?

The other main kind of empirical phenomenon is beliefs. We can distinguish three sorts of belief. The most general involves such things as what Wollstonecraft thought about the passions, how well Ferguson understood economics, and whether Machiavelli misquoted Dante intentionally or not. A second kind of belief is motives. Why did Marsilius of Padua write the Defensor minor? Why did Hobbes leave England in 1640? A third kind of belief is the intended meaning of a word, phrase, passage, or text. What did T.H. Green mean by "freedom"? What did Mill mean by "the permanent interests of man as a progressive being"?

Not all intellectual history is primarily empirical. We also ask questions which are partly conceptual and partly empirical, such as whether Spinoza was an atheist. This requires a definition of atheism (conceptual), and analysis of how well Spinoza's beliefs meet this definition (empirical). Some scholars, meanwhile, mainly ask logical questions, such as how valid Plato's reasoning is, or how consistent Bentham's arguments are. But logical questions often involve empirical claims about an author's intended meanings: for example, our assessment of the validity of Plato's reasoning depends partly on our view of how he understood dikaiosune. Normative questions can be seen as types of logical question (for example, do Sidgwick's conclusions follow from his premises?) and conceptual questions (for example, does Kant's categorical imperative meet the criteria of 
Habermasian discourse ethics?). Both kinds of normative question may thus include empirical claims about authors' beliefs.

So, most intellectual historians deal with empirical issues in one way or another.

\section{Empirical claims and uncertainty}

Every empirical claim is uncertain. We can never know how much Harriet Taylor influenced Mill's On Liberty. Even if Spinoza said that he believed in God, we can't be sure of his sincerity. Strictly speaking, we can't be certain that Hobbes wrote Leviathan, although there are no good reasons to doubt this. We can't even disprove apparent physical impossibilities. Did Aristotle translate the Cambridge University Press edition of the Politics while riding a motorbike made of kippers? Probably not, although it's just possible that he owned a time machine and a manual on fish-based transport. In practice, we exclude such possibilities, and we treat them in the same way as "Hobbes wrote Leviathan" - a claim which we have no good reason to doubt, and which we thus treat as a fact. But most empirical claims are less certain.

Uncertainty is a permanent feature of historical research. "The historian cannot have certain knowledge of ... the past," writes Collingwood. ${ }^{2}$ As Skinner puts it:

The outcome of the hermeneutic enterprise ... can never be anything resembling the attainment of a final, self-evident or indubitable set of truths about any text or any other utterance whatsoever. Even our most confident ascriptions of intentionality are nothing

\footnotetext{
${ }^{2}$ R.G. Collingwood, The Idea of History: Revised Edition, ed. Jan van der Dussen (Oxford: Oxford University Press, 1993), 487.
} 
more than inferences from the best evidence available to us, and as such are defeasible at any time. ${ }^{3}$

Skinner rebukes Derrida for falsely claiming that interpreters seek certainty. Rather, we try "to construct and corroborate plausible hypotheses about the intentions with which an utterance may have been issued," while accepting that such hypotheses "fall far short of certitude.."

Proof is unattainable, but Skinner thinks disproof is possible. We cannot know what Nietzsche meant by his obscure fragment "I have forgotten my umbrella." But "we definitely know that it cannot have been intended as an instruction or a question, simply because it is in the wrong grammatical mood." ${ }^{5}$ I disagree: statements in one grammatical mood can have a different meaning. "John has a long moustache" sounds like a description but, in June 1944, was a coded prescription: "prepare for invasion."

This highlights a deeper cause of uncertainty: "underdetermination," an ugly word for a crucially important idea. Underdetermination, also called indeterminacy, means that there are always different explanations of the same evidence -- different ways of joining the dots, so to speak. ${ }^{6}$ Fossils could reflect evolution, or God could have put them there; an odd experimental result might indicate random error, or a variable missing from the theory; Spinoza's statements about God may

\footnotetext{
${ }^{3}$ Quentin Skinner, Visions of Politics. Volume I: Regarding Method (Cambridge, UK: Cambridge University Press, 2002), 121.

${ }^{4}$ Ibid., 122; see also Quentin Skinner, "The Rise of, Challenge to and Prospects for a Collingwoodian Approach to the History of Political Thought," The History of Political Thought in National Context, ed. Dario Castiglione and lain Hampsher-Monk (Cambridge, UK: Cambridge University Press, 2001), 175-88, at 186-7.

${ }^{5}$ Ibid., 187.

${ }^{6}$ W. H. Newton-Smith, "Underdetermination of Theory by Data," in A Companion to the Philosophy of Science, ed. W.H. Newton-Smith (Oxford: Blackwell, 2000), 532-6.
} 
be sincere, or insincere. So, Popper was wrong: even apparently falsifying "facts" can be explained away. ${ }^{7}$ Proof is a dirty word in empirical research; so is disproof.

\section{Reducing uncertainty in intellectual history}

Accepting uncertainty is good; responding is better. I have learnt much from the work of Gary King, Robert Keohane and Sidney Verba, who see uncertainty as central to empirical research. ${ }^{8}$ They suggest that we try to reduce uncertainty by "improv[ing] our stock of valid inferences about the political world. ${ }^{\prime 9}$ Intellectual historians can take four actions: (a) exclude invalid data, (b) add valid data, (c) "triangulate" data, and (d) compare the strengths and weaknesses of different interpretations. I will briefly consider each one; more examples are discussed in relation to Noel Malcolm's work (section VII).

For intellectual historians, excluding invalid data means, for example, that if Plato did not write the Seventh Letter, we should not treat it as his work. Of course, we cannot be sure whether or not he wrote it -- so there will inevitably be uncertainty about excluding "invalid" data.

Adding valid data is easier for natural scientists, who can often run new experiments to generate new data, than for intellectual historians, for whom "the data are essentially finite." ${ }^{10}$ But we should not underestimate the possibilities. Hobbes scholars often used to ignore the second half of Leviathan and many of Hobbes's other works. Broader consultation can clarify Hobbes's

\footnotetext{
${ }^{7}$ Ibid., 534-5.

${ }^{8}$ Gary King, Robert Keohane and Sidney Verba, Designing Social Inquiry: Scientific Inference in Qualitative Research (Princeton: Princeton University Press, 1994), 8-9; see also 6, 31-2, 76, 79.

${ }^{9}$ Gary King, Robert Keohane and Sidney Verba, "The Importance of Research Design," in Rethinking Social Inquiry: Diverse Tools, Shared Standards, ed. Henry Brady and David Collier (Lanham: Rowman and Littlefield, 2004), 181-92, at 185.

${ }^{10}$ Jon Elster, Explaining Social Behavior: More Nuts and Bolts for the Social Sciences (Cambridge, UK: Cambridge University Press, 2007), 254; see also Hayden White, “A Conversation with Hayden White," Rethinking History 12 (2008), 3-21, at 8.
} 
comments and thus strengthen our confidence in our inferences. My claims about Hobbes's "cognitive" conception of corruption are made more plausible by finding similar comments about corruption in Hobbes's mathematical and political works. ${ }^{11}$

Triangulation, closely related, involves seeing if different kinds of data imply the same conclusions. For example, some Hobbes scholars supplement their textual reading of Leviathan with pictorial inferences from the frontispiece. ${ }^{12}$

Comparing the strengths and weaknesses of different interpretations is needed to avoid the "singing competition" fallacy: the first singer sounds so good that the judge awards the prize without hearing the other competitors. Clearly, if we only look for evidence which fits an interpretation, we are likely to overstate its plausibility. We should look for the strengths and weaknesses of our favored interpretation and of the alternatives. Time and word-limits often constrain such comparisons, of course.

The aim, overall, is to reduce uncertainty as far as possible. This will not always be very far, and will always be less than absolute certainty.

\section{Reporting uncertainty in intellectual history}

King, Keohane and Verba's other main suggestion is that we should try to report the level of uncertainty in our empirical claims. I will significantly amend King, Keohane and Verba's account; but their ideas provide an excellent springboard for intellectual historians.

"Without a reasonable estimate of uncertainty," write King, Keohane and Verba, "a description of the real world or an inference about a causal effect in the real world is

\footnotetext{
${ }^{11}$ Adrian Blau, “Hobbes on Corruption," History of Political Thought 30 (2009), 596-616, at 601-3, 605-10.

${ }^{12}$ Quentin Skinner, Hobbes and Republican Liberty (Cambridge, UK: Cambridge University Press, 2008), 185-7, 190-6.
} 
uninterpretable." A researcher who does not report uncertainty "is either asserting that he or she knows everything perfectly or that he or she has no idea how certain or uncertain the results are."13 We must thus give "honest statements of the degree of uncertainty entailed in each conclusion."14

This position is basically right, but it is not perfect: it is too strong in one respect, too weak in another, and incomplete in a third. It is too strong in that empirical claims are not "uninterpretable" without estimates of uncertainty. "P causes $Q$ " is no less interpretable than "P probably causes $Q$. ." Similarly, "Bentham believed in ghosts" is no less interpretable than "Bentham probably believed in ghosts." King, Keohane and Verba's position is also too weak: much turns on the meaning of "reasonable" and "honest" estimates of uncertainty; but King, Keohane and Verba say no more about this crucial issue. Before I offer some (partial) answers, I must address a profound incompleteness in King, Keohane and Verba's account.

King, Keohane and Verba argue that all empirical research, whether quantitative and qualitative, has the same logic of inference. ${ }^{15}$ They are emphatic that qualitative researchers should report estimates of uncertainty, like quantitative researchers. ${ }^{16}$ Yet they give "so little in the way of concrete guidance" about how qualitative researchers should tackle uncertainty that their book "can do little more than sensitize researchers to the general limitations of inference in the qualitative mode." ${ }^{\prime 17}$

Indeed, I will suggest that there are three profound differences between quantitative and qualitative indications of uncertainty. The first difference is fundamental: for statisticians, uncertainty is objective, but for intellectual historians, uncertainty is subjective. The other two

\footnotetext{
${ }^{13}$ King, Keohane and Verba, Designing Social Inquiry, 9; see also 32, 76, 152.

${ }^{14}$ King, Keohane and Verba, "The Importance of Research Design," 185; see also Designing Social Inquiry, 6.

${ }^{15}$ Ibid., 3-5.

${ }^{16}$ Ibid., 31-2, 152.

${ }^{17}$ Larry Bartels, "Some Unfulfilled Promises of Quantitative Imperialism," in Rethinking Social Inquiry, ed. Brady and Collier, 69-74, at 71.
} 
differences follow from the first: there is no agreed way of reporting subjective uncertainty, or of estimating it. I now consider each point in turn.

\section{V (i) Objective and subjective uncertainty}

King, Keohane and Verba are thinking about cases where the level of uncertainty is knowable, based on the properties of frequency distributions. ${ }^{18}$ The laws of statistics mean that we know two sets of data have a $95 \%$ chance of coming from the same parent population, say.

However, for intellectual historians, estimates of uncertainty are subjective, and indicate a person's degree of faith in a claim. If someone writes that Marx "probably" believed P, this means "I think the evidence is fairly strong that Marx believed P." Meanwhile, saying that Marx "almost certainly did not believe Q" means "I think the evidence is extremely strong that Marx did not believe $Q$, but I cannot discount it totally."

On this view, intellectual historians who make empirical claims are not saying what happened, but how strong they think their evidence is. (There are many similarities between subjective uncertainty and Bayesian ideas on probability. ${ }^{19}$ ) Subjective uncertainty is what Keynes discusses in his seminal Treatise on Probability: statements about probability refer to a belief about an event, not to the event itself. ${ }^{20}$ Keynes thinks this applies to probability in general; I am merely

\footnotetext{
${ }^{18}$ Gary King, Unifying Political Methodology: The Likelihood Theory of Statistical Inference (Cambridge, UK: Cambridge University Press,1989), 14-16, 23-8.

${ }^{19}$ James Press, Subjective and Objective Bayesian Statistics: Principles, Models, and Applications (Hoboken, NJ: John Wiley \& Sons, 2003; second edition), 5-7, 18-20.

20 John Maynard Keynes, A Treatise on Probability (London: Macmillan, 1921), 3-4.
} 
saying that it applies to statements about probability in intellectual history. (Quantitative researchers also make subjective judgments, of course. ${ }^{21}$ )

Collingwood seems to make a similar point. "The only knowledge that the historian claims is knowledge of the answer which the evidence in his possession gives to the question he is asking.... The certainty of history, then, is the certainty that the evidence in our possession points to one particular answer to the question we ask of it."22 This painful prose makes more sense, I believe, in the light of Collingwood's distinction between "what really happened" and "what the evidence indicates." Historians can know about the latter but not the former. Historians should find the view best supported by the evidence, and hope that this is also the correct view -- but cannot know this for certain. ${ }^{23}$ However, Collingwood proposes a false dichotomy, because he reifies "evidence"; yet our uncertainty about "what really happened" applies also to "evidence," since we do not know if our evidence is correct, as Collingwood recognizes elsewhere. ${ }^{24}$ We even disagree over what is evidence in the first place: Strauss sees Machiavelli's use of numbers as evidence of hidden meanings, Strauss's critics disagree. ${ }^{25}$ So, I do not accept Collingwood's implication that historians can know what the "evidence" indicates. Strictly speaking, we can only tell our readers how strong we think our empirical claims are, on the basis of what we take to be evidence.

Another way to think of this is with the idea of "category errors." A category error attributes a property to an object which it cannot have, such as "rocks believe in God." We sometimes

\footnotetext{
${ }^{21}$ Harold Brown, "Judgment, Role in Science," in A Companion to the Philosophy of Science, ed. W. H. NewtonSmith (Oxford: Blackwell, 2000), 194-202, at 194-5, 201-2,

${ }^{22}$ Collingwood, The Idea of History, 487. See also R.G. Collingwood, "The Limits of Historical Knowledge," Philosophy 3 (1928), 213-22, at 213-6. But compare R.G Collingwood, The Principles of History: And Other Writings in Philosophy of History, ed. William Dray and Jan van der Dussen (Oxford: Oxford University Press, 1999), 232-4.

${ }^{23}$ Collingwood, "The Limits of Historical Knowledge," 218-9.

${ }^{24}$ Collingwood, The Principles of History, 54.

${ }^{25}$ Leo Strauss, Thoughts on Machiavelli (Chicago: University of Chicago Press, 1958), 48-53, 344; J.G.A. Pocock, "Prophet and Inquisitor: Or, a Church Built upon Bayonets Cannot Stand: A Comment on Mansfield's 'Strauss's Machiavelli'," Political Theory 3 (1975), 385-401, at 394, 397.
} 
communicate using category errors, though: if someone says "America dislikes Communism," we might interpret this as meaning "most American citizens dislike Communism," or "leading American politicians dislike Communism," say, rather than fallaciously implying that a country can have beliefs. Something similar holds if we say "Plato probably wrote the Seventh Letter." Strictly speaking, this does not make sense. Plato wrote the Seventh Letter, or did not write it, or co-wrote it; but he could not "probably write" it. Consider, similarly, "Hobbes probably went to France out of fear." Hobbes went to France out of fear, or for a change of scene, or for both, or for other reasons; but he could not "probably go" anywhere. So, "Plato probably wrote this text" or "Hobbes probably went to France out of fear" mean "I think there is strong evidence that Plato wrote this text" or "I think there is strong evidence that Hobbes went to France out of fear."

Such beliefs may be mistaken, of course. Consider the Colloquium heptaplomeres, an anonymous sixteenth-century dialogue on religion. David Wootton and Noel Malcolm, the two scholars who I use below as exemplars of how to address uncertainty, differ profoundly on its authorship. Wootton writes that "I believe that I have almost conclusively proved that the Colloquium was not written by Bodin." Malcolm disagrees: "One is tempted to say that only Jean Bodin could have written it; but perhaps it is sufficient to say that there are ... no convincing reasons for thinking that he did not." ${ }^{26}$ Both authors give genuine indications of subjective uncertainty, but objectively, one of them is wrong about what the evidence suggests.

So, the job of researchers is to do their best to answer empirical questions, and then tell us how strong they think the evidence is for their conclusions. Researchers are not telling people what happened, but about their evidence for what they think may have happened. This need not be explicit where conclusions are beyond reasonable doubt. "Hobbes wrote Leviathan" is shorthand for

\footnotetext{
${ }^{26}$ Noel Malcolm, "Jean Bodin and the Authorship of the 'Colloquium Heptaplomeres'," Journal of the Warburg and Courtauld Institutes 69 (2006), 95-150.
} 
"it is beyond reasonable doubt that Hobbes wrote Leviathan." But such "facts" are, nonetheless, uncertain.

\section{V (ii) Reporting the degree of uncertainty}

One consequence of the subjectivity of historical uncertainty is that there is no agreed language for communicating degrees of uncertainty. Statisticians can report degrees of uncertainty in terms of significance levels, confidence intervals, standard deviations, and so on. Intellectual historians must use terms like "probably" and "likely." This is far less precise. If we say that Spinoza was "probably" an atheist, are we 90 percent sure? 75 percent sure? How low does "probably" go? 65 percent? 60 percent? Anything over 50 percent?

All is not lost, for four reasons. First, despite imprecision in the level of these terms, their order is usually discernible. For example, "almost certain" is stronger than "very likely," which is stronger than "likely" and "probable" (which sound equivalent to me, though doubtless not to everyone), which are stronger than "unlikely," which is stronger than "extremely unlikely." Most languages will have evolved such distinctions, although not all speakers of a language will agree on them. Interestingly, some distinctions in English are perverse: adding "surely" to a sentence indicates less certainty. ("Spinoza was an atheist" is more certain than "Spinoza was surely an atheist.") Second, intellectual historians sometimes merely indicate which of two explanations seems more certain. For example, Straussians might find their interpretations likelier than contextualist ones without needing to say how likely each interpretation is. Third, we sometimes reject explanations without proposing alternatives. A contextualist might pronounce a Straussian interpretation highly implausible, without offering a better solution. Fourth, subjective estimates of uncertainty are themselves so uncertain that there is no point seeking the precision of statistical uncertainty. This brings me to the next difference between objective and subjective uncertainty. 


\section{V (iii) Estimating the degree of uncertainty}

The other consequence of the subjectivity of historical uncertainty, and the third difference between subjective and objective uncertainty, is that there is no clear basis for making subjective estimates of uncertainty. Statisticians use the known properties of frequency distributions to automatically generate estimates of uncertainty, such as a $95 \%$ chance that two sets of data come from the same parent population. Intellectual historians have no such rules. How confident can we be in reading ideas into Rousseau's Social Contract from Emile, or from passages in the Geneva Manuscript which were cut from the final version of the Social Contract? There are no a priori answers to such questions. ${ }^{27}$ We get estimates of uncertainty retrospectively, trying out different interpretations and then estimating how plausible our inferences are. Subjective indications of uncertainty are, ultimately, "informed guesses." 28

This has two important corollaries. First, to help our readers assess our claims, we should be explicit about the evidence for our estimates of uncertainty (and our inferences, which are also informed guesses). We need not do this where there is no good reason to doubt a claim (such as "Hobbes wrote Leviathan"), where journal word-limits prevent us, or where it would unreasonably disrupt an argument; footnotes or appendices may help, though.

Second, we should try to make estimates of uncertainty reasonable..$^{29}$ As noted above, King, Keohane and Verba do not expand on this crucial notion. The following account is only a little more complete. ${ }^{30}$ The subjectivity of uncertainty does not mean that any old guess will do: reasonable

\footnotetext{
${ }^{27}$ A.P. Martinich, "Interpretation and Hobbes's Political Philosophy," Pacific Philosophical Quarterly 82 (2001), 309-31, at 317.

${ }^{28}$ E.D. Hirsch, Validity in Interpretation (New Haven: Yale University Press, 1967), 175.

${ }^{29}$ Keynes, Treatise on Probability, 3-4.

${ }^{30}$ For alternatives, see Donald Gillies, Philosophical Theories of Probability (London: Routledge, 2000), 53, 169 70, 174-5.
} 
estimates of uncertainty should be justifiable. Consider three examples. Someone claims to be "almost certain" about an interpretation, but turns out not to understand the relevant material. This is not a justifiable basis for estimating the plausibility of interpretations -- even if we agree, for different reasons, that the scholar's interpretation is almost certainly right. Next, consider a contextualist example. Quentin Skinner sometimes rejects an interpretation partly because none of the author's contemporaries read him like that. ${ }^{31}$ I regularly agree with Skinner's conclusions, but I do not find this particular line of reasoning too powerful: contemporaries can be mistaken. In my view, this adds less to the plausibility of Skinner's interpretations than he thinks. Consider, finally, a Straussian example. Strauss gives good a priori reasons for thinking that Maimonides writes esoterically: Maimonides discusses esoteric techniques and seems to use them himself. ${ }^{32}$ But Strauss cannot give such strong a priori reasons for esotericism in Machiavelli, who is not explicit about these techniques..$^{33}$ In this respect, Strauss's theoretical premises for his Machiavelli interpretations seem weaker; his claims about their plausibility should be less certain, other things being equal.

So, a reasonable estimate of uncertainty should be based on theoretical premises which should in turn be justifiable. Contextualists and Straussians who reject each others' theoretical premises will probably disagree about estimates of uncertainty too. Clearly, there is no consensus on what reasonable estimates of uncertainty are. But we should remember that even these broader theories are uncertain. We cannot know that no one is above the battle, ${ }^{34}$ or if an author is writing esoterically. ${ }^{35}$

\footnotetext{
${ }^{31}$ For example, Quentin Skinner, "The Ideological Context of Hobbes's Political Thought," The Historical Journal 9 (1966), 286-317, at 314-6.

32 Leo Strauss, Persecution and the Art of Writing (Glencoe: Free Press, 1952), 61-2, 69-70, 73. But compare Yair Lorberbaum, “On Contradictions, Rationality, Dialectics, and Esotericism in Maimonides's 'Guide of the Perplexed'," The Review of Metaphysics 55 (2002), 711-50.

${ }^{33}$ Strauss, Thoughts on Machiavelli, 24-6, 29-31, 36.

${ }^{34}$ Skinner, Hobbes and Republican Liberty, xvi.

${ }^{35}$ Strauss, Persecution and the Art of Writing, 26, 30
} 
In short, our interpretations are radically uncertain -- uncertain conclusions, uncertain estimates of the uncertainty of our conclusions, using unsystematic methods of estimating uncertainty and an unclear language for reporting it, all based on unprovable theoretical expectations. We cannot deny or decry this; it's part of the fun, and the pain, of intellectual history.

\section{Why report uncertainty, and how important is this?}

There are four main reasons to report uncertainty reasonably: two for the reader's sake, after publication, and two for the researcher's sake, before publication.

First, reporting uncertainty about an empirical claim helps our readers assess the plausibility of that claim. It is misleading to state, with equal certainty, "Machiavelli wrote The Prince" and "Machiavelli wrote The Prince as a satire." It is also misleading to understate certainty, pronouncing two alternatives as equally plausible when one is clearly likelier. ${ }^{36}$ Careful readers will see through such faulty summaries, though. (And when we read an argument presented with apparent certainty, we should remember that empirical claims cannot be known for certain.) Ultimately, the substance of scholarship is more important than reporting uncertainty. Imagine a scholar who rigorously analyses huge amounts of evidence, compares competing explanations, decides which explanation is strongest, but instead of describing it as "very likely," simply pronounces it "the right answer." This is not ideal, but is hardly a great crime. Ultimately, the quality of analysis matters more than reporting uncertainty.

Second, it is in a researcher's own interest to report uncertainty, as this implies good "character": we are showing readers that we are trying not to overstate our claims, and that we know we could be mistaken. (Rightly or wrongly, I find myself more likely to trust scholars who write

\footnotetext{
${ }^{36}$ Noel Malcolm, "The Printing and Editing of Hobbes's De Corpore: a Review of Karl Schuhmann's Edition," in New Critical Perspectives on Hobbes's Leviathan Upon the 350th Anniversary of Its Publication, ed. Luc Foisneau and George Wright (Milan: Franco Angeli, 2004), 329-57, at 335.
} 
like this than those who do not, especially as regards issues where I lack expertise.) If we have done our best and an interpretation is still highly uncertain, we should say so; if nothing else we will look less foolish if we or someone else later finds more support for an alternative claim. Reporting uncertainty is partly a defence mechanism.

Third, reporting uncertainty makes clearer to the researcher if more work is needed. If our estimates of uncertainty are honest and we keep noting that our inferences are possible but unlikely, we will seek more evidence, make different claims, or not publish at all. But if we know we are right, we are more likely to go wrong.

The fourth and most important reason for reporting uncertainty is thus to remind ourselves about the subjectivity of our research. Reporting uncertainty reminds us that as regards empirical claims, intellectual history is a subjective discipline: we are not telling our readers what happened, but how strong we think our evidence is. Reporting uncertainty reminds us that we can be wrong; it encourages self-doubt which, in moderation, can improve scholarship. Just as important as the logic of research is the disposition of the researcher. If we know we may be wrong, we are more likely to be right. If we open-mindedly and rigorously consider alternative interpretations, rather than becoming attached to an interpretation simply because it is ours, we are more likely to produce good scholarship. Uncertainty is an important part of this, but only a part.

This all suggests that reporting uncertainty is less important than taking it seriously in our research by trying to reduce it. Someone who evaluates competing interpretations carefully, plumps for one interpretation, and reports it without uncertainty, is producing better scholarship than someone who does not evaluate competing interpretations carefully, plumps for one interpretation, and tells us that it is "possible." 
I now turn from a theoretical discussion of uncertainty to examples of good practice. My two exemplars are Noel Malcolm and David Wootton, primarily with respect to uncertainty about composition and uncertainty about beliefs, respectively.

\section{Noel Malcolm}

Noel Malcolm's scrupulously careful analysis stands out both for the substance of his research and the way he assesses hypotheses with "judicious" caution. ${ }^{37}$ One such example is his study of the authorship of the Short Tract on First Principles, an anonymous and undated work on physics which Ferdinand Tönnies attributed to Hobbes in 1889 , potentially changing our understanding of Hobbes's influences, motivations and doctrines. Malcolm's analysis of the text's authorship is impressive because he "triangulates" different sources of evidence, which we can separate, roughly, into physical (including handwriting and how the manuscript was changed) and textual (including ideas and terms). Malcolm prefaces his analysis with a fine statement of how to deal with uncertainty:

in the absence of any single piece of strong and direct evidence ... any attribution must be based on putting together a pattern of less strong or less direct clues; and for each component of the pattern a possible alternative explanation might be found. ... All that a historian can do in such cases is to try to construct a pattern in which all the relevant evidence can be placed without strain, with as few unsupported assumptions as possible. ${ }^{38}$

\footnotetext{
${ }^{37}$ Edwin Curley, "Hobbes and the Cause of Religious Toleration," in The Cambridge Companion to Hobbes's Leviathan, ed. Patricia Springborg (Cambridge, UK: Cambridge University Press, 2007), 309-34, at 319.

${ }^{38}$ Noel Malcolm, Aspects of Hobbes (Oxford: Oxford University Press, 2002), 105-6.
} 
Malcolm's analysis builds on earlier work by Richard Tuck and Timothy Raylor. The latter argued that the Short Tract was written by Hobbes's friend, Robert Payne. Malcolm agrees that the manuscript is in Payne's hand. Handwriting does not prove authorship, of course, but aside from one piece of questionable evidence that Payne was copying out someone else's work, changes to the text also suggest that Payne was the author. ${ }^{39}$ Nonetheless, Malcolm accepts that the physical evidence "is far from conclusive." ${ }^{40}$

Malcolm thus moves to textual evidence, especially ideas and terms. Scholars who see the text's ideas as Hobbesian have fallaciously looked only at similarities between Hobbes's arguments and the Short Tract's; a full analysis requires examination of similarities and differences. ${ }^{41}$ Malcolm suggests that overall, the Short Tract "cannot easily be connected" with Hobbes's doctrines, and are far closer to Payne's. ${ }^{42}$ There are also striking terminological differences between the Short Tract and Hobbes's works. ${ }^{43}$ Combining the physical and textual evidence, Malcolm concludes that the Short Tract was "probably by Robert Payne." ${ }^{44}$ The abstract is firmer: the manuscript "was composed not by Hobbes ... but by Payne." ${ }^{\prime 4}$

Malcolm's study also stands out for its scrupulous evaluation of different hypotheses. This is worth emphasizing. Interpretation is always relative: underdetermination means there is always more than one way of explaining the evidence. Ideally we should thus assess competing interpretations. Another rigorous case of interpretative comparison is Malcolm's discussion of

\footnotetext{
39 Ibid., 106-8.

${ }^{40}$ Ibid., 110.

${ }^{41}$ Ibid., 130.

${ }^{42}$ Ibid., 110-26.

${ }^{43}$ Ibid., 129-30.

${ }^{44}$ Ibid., 52.

${ }^{45}$ Ibid., 80.
} 
whether Hobbes was the translator of the English version of De Corpore. ${ }^{46}$ Karl Schuhmann, in contrast, sometimes takes a single hypothesis and looks for evidence which fits it, leading to "highly implausible" claims about the printing history of Leviathan's editions. ${ }^{47}$

The above examples primarily involve textual composition. Malcolm writes less about beliefs, the second kind of empirical phenomenon discussed above. Here too, though, he often tries to give reasonable estimates of uncertainty, about what Hobbes meant when he said that grief "ariseth from" imagination, ${ }^{48}$ or how Hobbes understood the terms "Behemoth," "Leviathan," and "the people." ${ }^{49}$ Sometimes Malcolm is very cautious: for example, discussing which of his aristocratic patrons Hobbes was ideologically closer to in the 1620s, Malcolm states that "the sort of evidence that would enable one to answer that question with confidence is lacking." Until 1640 we have "very little direct evidence" of Hobbes's position, and the indirect evidence is "ambiguous or inconclusive. ${ }^{150}$ But Malcolm is not slow to talk in absolutes where the evidence merits it, as when rejecting common interpretations of Hobbes's theory of international relations. ${ }^{51}$ For example, as regards the view that the state of nature was an amoral state, Malcolm writes: "Hobbes does not say that." ${ }^{152}$ We do not need indications of uncertainty when rejecting false claims about what an author wrote.

\footnotetext{
${ }^{46}$ Malcolm, "The Printing and Editing of Hobbes's De Corpore," 334-6.

${ }^{47}$ Noel Malcolm, "Changing the Sheets: A Game of Blind Man's Buff with Leviathan," Times Literary Supplement, 3 December 2004 (http://www.timesonline.co.uk/tol/incomingFeeds/article749047.ece, accessed 12 September 2008); Noel Malcolm, "The Making of the Bear: Further Thoughts on the Printing of the Second Edition of Leviathan," Hobbes Studies 20 (2007), 2-39.

${ }^{48}$ Malcolm, Aspects of Hobbes, 31.

${ }^{49}$ Noel Malcolm, "The Name And Nature of Leviathan: Political Symbolism and Biblical Exegesis," Intellectual History Review 17 (2007), 21-39, at 23, 34-9; Malcolm, Aspects of Hobbes, 37.

${ }^{50}$ Noel Malcolm, Reason of State, Propaganda, and the Thirty Years' War: An Unknown Translation by Thomas Hobbes (Oxford: Clarendon Press, 2007), 82-91; quotations at 82.

${ }^{51}$ Malcolm, Aspects of Hobbes, 435-55.

${ }^{52}$ Malcolm, Aspects of Hobbes, 438.
} 


\section{David Wootton}

My second exemplar, David Wootton, accepts that we can be definitive about what people wrote but only "speculative" about their beliefs. For historians, "no case is ever closed." Even if we resolve apparent contradictions in authors' statements, the "possibility of incoherence ... can never be finally eliminated. ${ }^{153}$ Wootton tries to reduce uncertainty, too, by amassing evidence and comparing rival interpretations, as with his analysis of the religious views of Paolo Sarpi (1552-1623), the Venetian historian and thinker. ${ }^{54}$

Wootton often denotes uncertainty with clauses like "I think," "I believe," and "I will suggest": for example, "I think it is correct to say that Hume never had a strong sense of human diversity. ${ }^{\prime \prime 5}$ Elsewhere, especially in his early writings, he uses more refined indications. For example, Sarpi's idea of sovereignty was "probably drawn from Bodin," and his account of churchstate struggles "looks very like" a reference to actual events, such that "I find it hard to believe that Sarpi is not thinking of Venice." ${ }^{156}$

Wootton also distinguishes between relative likelihoods, as when asking whether some writers hinted at their religious views indirectly rather than explicitly. With Boulainvilliers, the inconsistency "is so blatant that I think one is bound to conclude that Boulainvilliers knew what he was doing." But "it is dangerous to assume that authors must always be aware of their own

\footnotetext{
${ }^{53}$ David Wootton, Paolo Sarpi: Between Renaissance and Enlightenment (Cambridge, UK: Cambridge University Press, 1983), 7, 145.

${ }^{54}$ Wootton, Paolo Sarpi, especially ch. 4.

${ }^{55}$ David Wootton, "Narrative, Irony, and Faith in Gibbon's Decline and Fall," History and Theory 33 (1994), 77105 , at 103.

${ }^{56}$ Wootton, Paolo Sarpi, 20-1, 51, 152-3.
} 
inconsistencies," and with Bayle "there is room for uncertainty" about whether he knew what he was doing at the time. ${ }^{57}$

Wootton's discussion of Sarpi's religious views contains many indications of uncertainty. Wootton compares six interpretations of Sarpi's views and concludes: "the evidence strongly suggests that the Pensieri [Sarpi's private notebooks] represent Sarpi's true convictions." Wootton rejects four interpretations: that Sarpi was an orthodox Catholic, a Catholic reformer, an Anglican, and a Protestant. A fifth interpretation, that Sarpi was an eirenicist, fits all of the evidence except the Pensieri, which suggest a sixth interpretation: Sarpi "did not, strictly speaking, believe in a spiritual, non-doctrinal religion, but ... advocated it as the best sort of religion." This was based on "a materialist agnosticism," and a "psychological and social" account of religion, not a supernatural one. "The real Sarpi must be presumed to be the Sarpi of the Pensieri because no other hypothesis can satisfactorily explain the contradictions running through his life. Either Sarpi was a man with no consistent principle or purpose, or else his principles and purposes derive from the Pensieri." Sarpi's History of the Inquisition (1613) seems to undercut this interpretation, but for Wootton the text is a modest change in strategy, not a fundamental shift in ideals. Wootton accepts that the text is "the most telling evidence" against his interpretation, but his interpretation is still "at the least ... plausible." ${ }^{158}$

Wootton probably overstates himself in claiming that Sarpi's letter to Badoer "makes my interpretation convincing." In rejecting the possibility that Sarpi is simply voicing his reader's views -a standard tactic of the chameleon-like Sarpi -- Wootton places great weight on the letter's tone. Sarpi's usual tone is dry and detached, but in the letter to Badoer, and only there, we see "an expression of genuine feeling, an expression which serves no purpose other than that of overcoming

\footnotetext{
${ }^{57}$ David Wootton, "Lucien Febvre and the Problem of Unbelief in the Early Modern Period," The Journal of Modern History 60 (1988), 695-730, at 710.

${ }^{58}$ Wootton, Paolo Sarpi, 120-7.
} 
an oppressive loneliness, in confiding in a distant friend. ${ }^{.59}$ In my view, such stylistic evidence is far from conclusive; at most this makes Wootton's interpretation more convincing, but not "convincing."

This overstatement aside, Wootton accepts that his explanation may be wrong and that Sarpi could have changed his views later on. ${ }^{60}$ Wootton mostly avoids implying that his answer is right; rather, this "interpretation" is "what seems to me the correct account." It is a "hypothesis" which best fits "the evidence." ${ }^{61}$

Interestingly, two reviews of Wootton's book criticize his uncertainty. One reviewer thinks that these indications of uncertainty imply that "Wootton is often troubled about the inadequacy of his sources and admits to arguing by inference alone." ${ }^{62}$ This seems unfair and misleading. Another reviewer complains that when discussing Sarpi's views on free will, Wootton "offers no help by expressing his own uncertainty about Sarpi's motives. ${ }^{\prime 63}$ I disagree. We do help our readers by weighing up competing explanations and then indicating how strongly they are supported by the evidence; we do not help our readers by presenting markedly uncertain interpretations as if they are right.

Inevitably, in many places Wootton does not voice uncertainty. Sometimes there is no need: for example, having repeatedly demonstrated Sarpi's non-religious principles, Wootton can legitimately state that Sarpi's motivations for attacking the papacy "were always ... secular, rather than religious, ${ }^{164}$ even though strictly speaking we do not know this for certain. Sometimes,

\footnotetext{
${ }^{59}$ Ibid., 128-130.

${ }^{60}$ Ibid., 133.

${ }^{61}$ Ibid., 120, 123-4, 127-8.

${ }^{62}$ Eric Cochrane, [Book Review], The Journal of Modern History 57 (1985), 151-153, at 152.

${ }^{63}$ Elisabeth Gleason, [Book Review], Renaissance Quarterly 37 (1984), 622-624, at 624.

${ }^{64}$ Wootton, Paolo Sarpi, 93.
} 
Wootton initially voices uncertainty and then stops: for example, he first indicates uncertainty about why Sarpi used a particular wordbut then describes Sarpi's intentions without uncertainty, ${ }^{65}$ which is a touch too strong.

Sometimes, though, Wootton is definitely too bold. For example, in his (deeply unfair) review of Skinner's Visions of Politics, he berates Skinner for overlooking “Hobbes's preoccupation with fear, an emotion in which Hobbes grounds the whole edifice of his political theory, and which he acknowledges as his own characteristic mental state -- fear and he, he tells us, were born twins. ${ }^{\prime 66}$ These are significant overstatements. Hobbes does say that his mother gave birth to twins: "Me, and Fear." ${ }^{67}$ But it is quite a leap to see this as his "characteristic mental state." And while Hobbes says that he fled to France out of fear, ${ }^{68}$ the move may have been at least partly premeditated. ${ }^{69}$ Many scholars now deny that fear is the basis of his political theory. ${ }^{70}$ It is thus unlikely that Hobbes had a "preoccupation" with fear -- a view I too have voiced but which I now think too strong. ${ }^{71}$

Wootton is hardly alone in such overenthusiastic interpretation. ${ }^{72}$ Like many methodological prescriptions, reducing and reporting uncertainty are ideals which we regularly violate: life is too

${ }^{65}$ Ibid., 21-2.

${ }^{66}$ David Wootton, “The Hard Look Back," Times Literary Supplement, 14 March 2003, 8-10, at 8.

${ }^{67}$ Thomas Hobbes, Verse Life, in Thomas Hobbes, Human Nature and De Corpore Politico, ed. J.C.A. Gaskin (Oxford: Oxford University Press, 1994), 254.

${ }^{68}$ Thomas Hobbes, Prose Life, in Hobbes, Human Nature and De Corpore Politico, 247.

${ }^{69}$ Noel Malcolm, “Hobbes, Thomas (1588-1679)," Oxford Dictionary of National Biography (Oxford: Oxford University Press, 2004; online edition, Jan 2008), http://www.oxforddnb.com/view/article/13400, accessed 31 Jan 2009.

${ }^{70}$ See in particular Sharon Lloyd, Ideals as Interests in Hobbes's Leviathan: The Power of Mind over Matter (Cambridge, UK: Cambridge University Press, 1992), 36-7, 254.

${ }^{71}$ Adrian Blau, "Hobbes," in The Dictionary of Liberal Thought, ed. Duncan Brack and Ed Randall (London: Politicos, 2007), 168-70, at 168.

72 Behan McCullagh, The Logic of History: Putting Postmodernism in Perspective (London: Routledge, 2004), $37-$ 9. 
short. (Or at least, journal articles are too short.) My own substantive research errs in the same respects. My study of Hobbes's language of corruption does not reduce uncertainty far enough: further historical research would have helped. ${ }^{73}$ And my claims about Hobbes's views on mixed government are plausible but, strictly speaking, overly certain. ${ }^{74}$

Wootton's occasional overstatements should not deflect us from the key message of this section: Wootton emphasizes the evidence, not the answer; he evaluates competing interpretations and tries to see which fits best; and he often gives indications of the uncertainty of his conclusions about authors' beliefs.

\section{Conclusion}

The idea of uncertainty is one part of a web of related ideas: empirical claims are always uncertain and always open to different interpretations, so intellectual historians should ideally test different hypotheses, giving relative and absolute indications of each one's plausibility, having reduced uncertainty as far as possible.

Ultimately, taking uncertainty seriously is most important for its effect on the research process itself. Uncertainty reminds researchers about the dangers of evidence misleading them, and of them misreading evidence. Uncertainty requires us to ask if our theoretical expectations are right, if we have focused overly on a single explanation, if we have looked at the similarities and differences, the strengths and weaknesses, of plausible alternatives. Ignoring uncertainty by no means precludes high-class research. But it does make errors likelier.

\footnotetext{
${ }^{73}$ Blau, "Hobbes on Corruption."

${ }^{74}$ Ibid., 601, 615.
} 